\title{
Confirmation of the presence of Alsodes pehuenche Cei, 1976 (Anura, Alsodidae) in Chile: morphological, chromosomal and molecular evidence
}

\section{Confirmación de la presencia de Alsodes pehuenche Cei, 1976 (Anura, Alsodidae) en Chile: evidencia morfológica, cromosómica y molecular}

\author{
Claudio Correa ${ }^{1,2, *}$, Luis Pastenes ${ }^{2}$, Patricia Iturra ${ }^{3}$, Pilar Calderón ${ }^{4}$, Dayana Vásquez ${ }^{2}$, Natalia \\ Lam ${ }^{3}$, Hugo Salinas ${ }^{2}$ \& Marco A. MÉndez $z^{2}$ \\ ${ }^{1}$ Laboratorio de Biología Evolutiva, Departamento de Ecología, Pontificia Universidad Católica de Chile, Alameda 340, \\ Santiago, Chile. \\ 'Laboratorio de Genética y Evolución, Facultad de Ciencias, Departamento de Ciencias Ecológicas, Universidad de Chile, \\ Las Palmeras 3425, Santiago, Chile. \\ ${ }^{3}$ Laboratorio de Citogenética y Genética Poblacional de Vertebrados, Instituto de Ciencias Biomédicas, Facultad de Medicina, \\ Universidad de Chile, Independencia 1027, Santiago, Chile. \\ ${ }^{4}$ Fundación Senda Darwin, Casilla 114-D, Santiago, Chile. \\ "correasp@gmail.com
}

\begin{abstract}
The presence of Alsodes pehuenche in Chile was reported in the year 2010, based on the observation of larvae near the Chilean-Argentinean border, about $3 \mathrm{~km}$ east of the northeast corner of the Laguna del Maule (Región del Maule, Chile). The taxonomic history of this species dates from 1965, with the re-discovery of Telmatobius montanus (which was later transferred to the genus Alsodes) in two localities, near the Laguna del Maule and Valle Pehuenche, located in Chile and Argentina, respectively. The literature review shows that the locality of Argentina described in 1965 became the type locality of $A$. pehuenche, while the Chilean locality was ignored; thus this latter locality continues to be a valid record for A. montanus. In this study we provide morphological, chromosomal and molecular evidence, which confirms the presence of A. pehuenche in Chile, in two new localities located near the site recorded in 2010 and the Laguna del Maule. We also include some field observations, which are discussed in the context of the information available for this species.
\end{abstract}

KeYwords: Andes Range, Laguna del Maule, microendemism, spiny-chest frog, Valle Pehuenche.

\section{RESUMEN}

La presencia de Alsodes pehuenche en Chile fue reportada en el año 2010, a partir de la observación de larvas en las cercanías del límite entre Chile y Argentina, aproximadamente a $3 \mathrm{~km}$ al este del extremo noreste de la Laguna del Maule (Región del Maule, Chile). La historia taxonómica de esta especie se remonta a 1965, cuando se redescubrió a Telmatobius montanus (especie que luego fue transferida al género Alsodes) en dos localidades, cerca de la Laguna del Maule y Valle Pehuenche, ubicadas en Chile y Argentina, respectivamente. La revisión bibliográfica muestra que la localidad de Argentina descrita en 1965 pasó a ser la localidad tipo de A. pehuenche, mientras que la de Chile fue ignorada posteriormente, por lo que esta última continúa siendo un registro válido de $A$. montanus. En este trabajo se provee evidencia morfológica, cromosómica y molecular que confirma la presencia de a $A$. pehuenche en Chile, en dos localidades ubicadas cerca del sitio reportado en 2010 y de la Laguna del Maule. Además, se incluyen algunas observaciones de terreno que son discutidas en el contexto de la información disponible de la especie.

Palabras clave: Laguna del Maule, Los Andes, microendemismo, rana de pecho espinoso, Valle Pehuenche. 


\section{INTRODUCTION}

The Chilean batrachian fauna has a low number of species in comparison to other countries of South America; however, it has a high degree of endemism (Vidal 2008; Correa et al. 2011; IUCN 2013). Currently the majority of these endemic species are known only from the type locality (Correa et al. 2011), suggesting that they have very reduced distribution ranges (microendemism). Although this is a relevant aspect from an evolutionary and biogeographic viewpoint, the reduced distribution ranges may simply be the result of a lack of exploration or to the destruction and/or fragmentation of the habitat. In any event, establishing whether a reduced distribution range is a natural phenomenon or a consequence of anthropic activities is essential to evaluate the conservation status of a species and generate measures to protect it.

The Chilean amphibian species, which may be considered as microendemic are found mainly in the Altiplano zone in the extreme northeast (Telmatobius), in the Andes Range in the central zone (Alsodes) and in the temperate forests of the south (Alsodes, Eupsophus and Insuetophrynus). The genus Alsodes has the largest number of species described among the amphibians of Chile, and also has the largest number of species known only from the type locality (Correa et al. 2011). Although most of these species are found in the temperate forests of Chile, there are four $(A$. hugoi, A. montanus, A. tumultuosus and A. pehuenche) which are restricted to the Andes foothills and mountains. Alsodes pehuenche was previously known only from Valle Pehuenche, Mendoza Province, Argentina (Cei 1976, 1980), but was recently reported for Chile based on the observation of larvae (Corbalán et al. 2010).

The report of $A$. pehuenche in Chile illustrates that in some cases it is necessary to perform detailed taxonomic studies to support such findings. Corbalán et al. (2010) described the presence of this species in Chile in a small valley in the western slopes of the Andes range, located about $4 \mathrm{~km}$ in straight line from the type locality, Valle Pehuenche in Argentina (which is located in the eastern slopes of the Andes Range), and approximately $3 \mathrm{~km}$ from the northeast corner of the Laguna del Maule (see Fig. 1c). In this new Chilean locality, these authors only observed numerous larvae, which were assigned to A. pehuenche, but they did not indicate the larval characteristics used for the identification. Another possibility is that they have applied implicitly the criterion of geographic proximity. Although in this case this criterion appears to be reasonable, its application faces two problems, one of which has a bibliographic origin.

The first problem has to do with the external larval morphology. The larvae of the different species of Alsodes are very similar both in size and coloration (Díaz \& Valencia 1985). These authors made the only attempt to date to establish differences between the larvae of several species of the genus, and almost none of the species described after this publication (e.g. Formas et al. 1997; Cuevas \& Formas 2005; Cuevas 2008) have included larval characters in their diagnoses. It must be noted that the description of A. pehuenche also does not include larval characters (Cei 1976). The second problem derives from the report of Cei \& Roig (1965). These authors published an account of the rediscovery of Telmatobius montanus (later transferred to the genus Alsodes) in two localities, one in Chile and one in Argentina, located $200 \mathrm{~km}$ south of the original site in which this species was described (an indeterminate site between $33^{\circ}$ and $34^{\circ} \mathrm{S}$ ). Later, the Argentine population (Valle Pehuenche) was described as A. pehuenche (Cei 1976), but the Chilean locality, located $15 \mathrm{~km}$ from the border with Argentina near the Laguna del Maule, was completely ignored in the later literature. Even recent articles dealing with the distribution of $A$. montanus (Araya \& Riveros 2008; Correa et al. 2008a) do not mention this locality.

Since Cei (1976) did not include the Chilean locality of Cei \& Roig (1965) when he described A. pehuenche, the site may still be considered as a valid record of $A$. montanus. In addition, if a criterion of geographic proximity was used by Corbalán et al. (2010), this is weakened by the recent range extension of $170 \mathrm{~km}$ to the south reported for $A$. montanus (to $34^{\circ} 57^{\prime}$ S, Araya \& Riveros 2008), and by the fact that the type locality of $A$. hugoi (Altos de Vilches) is only $75 \mathrm{~km}$ northwest of the Laguna del Maule (Cuevas \& Formas 2001).

In this study we compare the external morphology of adults of two Chilean localities near the Laguna del Maule with the descriptions of $A$. pehuenche available in the literature (Cei 1976, 1980; Corbalán et al. 2010). Additionally, we also provide chromosomal and molecular (partial sequences of cytochrome $b$ ) evidence to elucidate the specific status of these populations, along with field observations which complements the available information of the species.

\section{MATERIALS AND METHODS}

\section{STUDY AREA AND MATERIAL}

The two localities included in this study are located on the western slopes of the Andes range, in the Región del Maule, Chile, less than $6 \mathrm{~km}$ in straight line from the border with Argentina (Fig. 1c). Both sites are located on the northern side of the international road ( $\mathrm{CH}-115)$. One of these localities is approximately $900 \mathrm{~m}$ north $\left(35^{\circ} 59^{\prime} 32.7^{\prime \prime}\right.$ $\mathrm{S} ; 70^{\circ} 24^{\prime} 06.2^{\prime \prime} \mathrm{W} ; 2493 \mathrm{~m}$ ) of the Chilean site reported by Corbalán et al. (2010), and $3.5 \mathrm{~km}$ east of Laguna del Maule, 
in straight line. This locality is a small valley with slight slope with a stream bed of sand and rocks, which crosses a wide, grass-covered plain. On the date of the sampling and observations (March, 2012, austral autumn) the water level was low, with part of the bed dry and with wide areas with water on the borders which formed pools surrounded by vegetation (Fig. 1a). In the surrounding area of the stream, in the widest and flattest part, numerous burrows of the rodent Ctenomys maulinus (tunduco) were observed. In a nocturnal exploration we collected four adults (two males and two females) of Alsodes. Six additional males and four females were captured, measured (snout-vent length) and liberated in the capture site. We observed five more adults, which were not measured, and numerous larvae in different development stages. We also observed two postmetamorphic and one adult individual of the amphibian Pleurodema bufoninum moving in the vegetation near the water. The second locality is approximately $3.4 \mathrm{~km}$ west, in straight line (3559'54.6” S; 70²6’30.5” W; $2228 \mathrm{~m}$ ), of the Chilean site reported by Corbalán et al. (2010), and is very close to the northeast corner of Laguna del Maule. It is a narrower watercourse with a steeper slope than that of the first locality. Rocks of different sizes in the border and bed of this stream allow the formation of pools with slower water flow in some sectors. This site is very similar to the stream shown in Figure 2 of Corbalán et al. (2010), with a similar vegetation cover in the borders. In this locality we only observed six female adults of Alsodes, one of which was collected (none was measured). Captured individuals were treated according to the guidelines of the Ethics Committee of the Universidad de Chile, which are based on the recommendations of the National Research Council (USA) (1996). The five collected individuals were deposited in the herpetological collection of the Departamento de Biología Celular y Genética of the Universidad de Chile (DBGUCH), with collection numbers 1203023-026 (first locality) and 1203027 (second locality).

\section{KARYOTYPING}

The chromosome preparations were obtained from epithelial intestine tissue of two individuals captured in the first locality, 1203023 (male) and 1203024 (female). Animals were inoculated in the abdominal region with a $1 \% \mathrm{w} / \mathrm{v}$ colchicine solution $(0.5 \mathrm{mg} / \mathrm{g}$ live weight $)$. After four hours the animals were euthanized with an overdose of $0.2 \%$ tricaine $(\mathrm{w} / \mathrm{v})$, after which the intestine was extracted. Fragments of intestine were submerged in distilled water for $20 \mathrm{~min}$ and then fixed in a $50 \%(\mathrm{v} / \mathrm{v})$ solution of acetic acid. Metaphase plates were obtained by the squash technique and stained with the conventional Giemsa technique (4\% $\mathrm{v} / \mathrm{v})$. The NOR-bearing chromosome was identified using fluorescent banding with Chromomycin $\mathrm{A}_{3}$ according to
Araya (2011). Chromosome number was established by analyzing 50 metaphases of each individual. Chromosome pairs were ordered by size and morphology. Chromosome observations used an Optiphot-2 (Nikon, Melville, NY) microscope; the preparations were photographed with a Nikon CCD digital camera. The karyotype was compared with that reported by Cuevas \& Formas (2003) for $A$. pehuenche from Valle Pehuenche, Argentina.

\section{DNA SEQUENCES}

We amplified a fragment of the mitochondrial cytochrome $\mathrm{b}$ gene for the five individuals captured, using the primers MVZ15-L (Moritz et al. 1992) and CytbAR-H (Goebel et al. 1999). The final concentrations or quantities of the PCR mix were: $3 \mathrm{mM} \mathrm{MgCl}, 0.12 \mathrm{mM}$ of each dNTP, $83.3 \mathrm{nM}$ of each primer, $1 \mathrm{U}$ Taq polymerase (Invitrogen, Carlsbad, CA) and 50-100 ng of total DNA. The thermal profile of the reaction was: $94^{\circ} \mathrm{C}$ for $3 \mathrm{~min}$, followed by 42 cycles of $94^{\circ} \mathrm{C}$ for $40 \mathrm{~s}, 56^{\circ} \mathrm{C}$ for $50 \mathrm{~s}$ and $72^{\circ} \mathrm{C}$ for $60 \mathrm{~s}$, with a final extension at $72^{\circ} \mathrm{C}$ for $10 \mathrm{~min}$. PCR products were sequenced in both directions in an ABI3730XL (Macrogen Inc., Seoul, Korea) genetic analyzer. The resultant sequences were inspected and edited by eye in the BioEdit v.7.1.3.0 program (Hall 1999), and then they were compared with a sequence of $A$. pehuenche from Valle Pehuenche, Argentina (Blotto et al. 2013; IZUA 3559, GenBank accession number JX203962).

\section{RESULTS}

\section{AdulT MORPHOLOGY}

We captured 15 adults of Alsodes (eight males and seven females, including one female from the second locality) and recorded the snout-vent length (SVL) and other external morphological characteristics. The mean SVL for males was $51 \mathrm{~mm}$ and for females $50.4 \mathrm{~mm}$. These frogs have a bulky body and robust extremities, especially the anterior legs of the males (Fig. 1b). The tips of the toes are rounded and whitish in color; interdigital membranes are present only in the posterior extremities. The head is wider than long; the snout is short and rounded. Males have folds of loose skin on the sides of the body and behind the thighs which are not evident in females. The dorsal skin is light brown with diffuse, irregular, darker blotches. Occasionally they have dispersed yellowish blotches, more frequent in females. The ventral skin is cream colored in both sexes. Adult males present pectoral patches with small, uniformly distributed, keratinized black spines (Fig. 1b), as well as spines in the internal border of the first and second fingers. All these characteristics agree with the descriptions of $A$. pehuenche reported by Cei \& Roig (1965), Cei (1976, 1980) and Corbalán et al. (2010). 

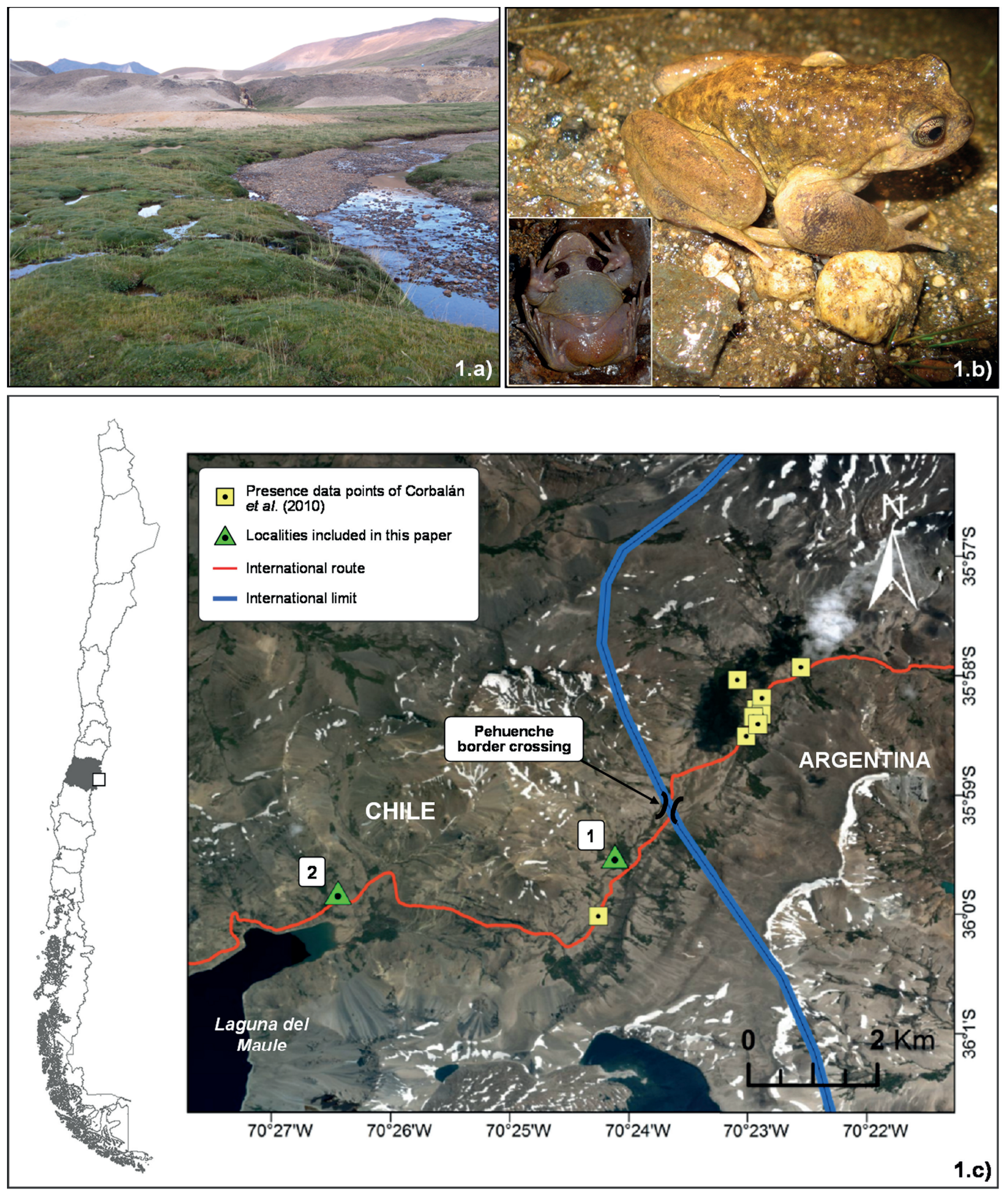

Figure 1. (1.a). Panoramic view of the new locality of Alsodes pehuenche from Chile (first locality in the text). (1.b). Adult male from the same locality. (1.c). Map of the known localities of $A$. pehuenche in Chile and Argentina.

Figura 1. (1.a). Vista panorámica de la nueva localidad de Alsodes pehuenche de Chile (primera localidad en el texto). (1.b). Macho adulto de la misma localidad. (1.c). Mapa de las localidades conocidas de A. pehuenche en Chile y Argentina. 


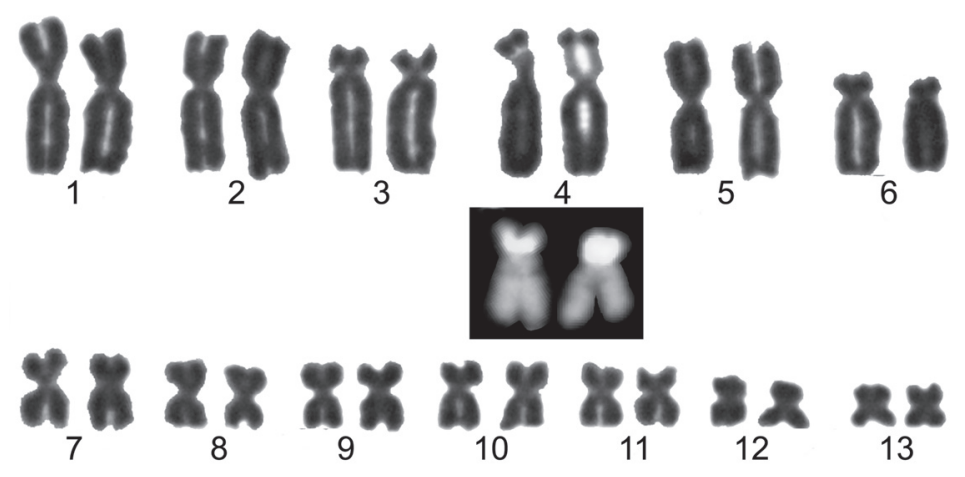

FIGURE 2. Karyotype of an adult male of Alsodes pehuenche (DBGUCH 1203023). The box shows the chromosome pair which carry the NOR, stained with the fluorochrome Cromomycin $\mathrm{A}_{3}$.

Figura 2. Cariotipo de un macho adulto de Alsodes pehuenche (DBGUCH 1203023). El recuadro muestra el par de cromosomas portador del NOR, teñido con el fluorocromo Cromomicina $\mathrm{A}_{3}$.

\section{KARYOTYPE}

The two individuals analyzed presented a karyotype of $2 n=26$ (Fig. 2). All chromosome pairs are bibrachiate and metacentric, except for pairs 3 and 6 which are subtelocentric. Pair 4 showed a brilliant positive band of Chromomycin $\mathrm{A}_{3}$ in the short arm where the NOR is located (Fig. 2). This karyotype concurs with that of $A$. pehuenche from Valle Pehuenche, Argentina, reported by Cuevas \& Formas (2003).

\section{MitochONDRIAL SEQUENCES}

We obtained sequences of 990 nucleotides for the five collected frogs from the two localities. The five sequences obtained here and that one of $A$. pehuenche from Valle Pehuenche (Blotto et al. 2013) were all identical. The sequences obtained in this study were deposited in GenBank with accession numbers JX494349-JX494353.

\section{DISCUSSION}

The morphological, chromosomal and molecular information presented here confirms the presence of $A$. pehuenche in Chile, which was first reported for the country by Corbalán et al. (2010). In addition, the discovery of a locality $3.4 \mathrm{~km}$ west from the Chilean locality reported by those authors suggests that the distribution of this species is significantly major (at least 50\% more) than the area shown by them. However, the taxonomic identity of the Chilean population of $A$. montanus mentioned by Cei \& Roig (1965) must still be resolved. Neither of the two localities of this study concurs with the location of their reported site (" $15 \mathrm{~km}$ from the Argentinian frontier, 2,400 m, facing Maule Lake, Talca, Chile"), nor we could find a place that matched that distance from the frontier and that height; thus this report may still be considered as a valid record for $A$. montanus.
On the other hand, Cei (1976), for unknown reasons, did not even mention the Chilean locality reported by Cei \& Roig (1965) in his description of A. pehuenche. Since Cei (1976) did not provide arguments to differentiate the individuals of Valle Pehuenche (Mendoza Province, Argentina) from those of the Chilean locality, both populations may be considered as belonging to the same species (A. pehuenche). This suggests the need for an intensive exploration of the mountainous zone between $34^{\circ}$ and $36^{\circ} \mathrm{S}$, to establish the distribution ranges of $A$. montanus and $A$. pehuenche, and thus make clear the taxonomic status of the Chilean population described by Cei \& Roig (1965).

The observations reported here for the two new Chilean localities of $A$. pehuenche allow reconsidering some ecological aspects mentioned by Cei \& Roig (1965) and Corbalán et al. (2010). Cei \& Roig (1965) suggested the possibility that adult individuals excavated the deep holes in which they hide, which reach until $1.5 \mathrm{~m}$ depth. In our sampling, most of the adults captured in the first locality were found in cavities which were shallower $(<1 \mathrm{~m})$; also, we found that under the vegetation which borders the watercourse there is an almost continuous cavity at the water level, probably caused by undermining. Given this availability of potential refuge sites, it seems unnecessary to attribute to these animals the capacity to dig these deep holes.

We also confirmed the vocal activity of this species. According to Cei \& Roig (1965), the call of this amphibian is "deep but weak", and may be heard irregularly during the day and underwater. Our observations agree that $A$. pehuenche has a weak vocalization (not deep); however, we could not verify that calls were made underwater. Before nightfall the vocalizations came from the cavities in the border of the watercourse, which allowed us to locate the 
animals; however, after dark the calls ceased and males and females were observed submerged or semi-submerged in the water.

Our observations also provide information about the abundance of this species in the watercourses it inhabits. Although we did not obtain enough data to estimate the number of adult individuals in the two populations we studied, several facts suggest that there is high local abundance. In the first locality we observed about 20 adults in a period of one hour in less than $30 \mathrm{~m}$ of the watercourse. We also observed that during the day several adult individuals shared the same cavity, which indicates that the density is high at the microhabitat level. Moreover, in the second locality (with greater slope) within a 15-minute period we observed six semi-submerged individuals in a stretch of $40 \mathrm{~m}$. These observations suggest that the number of metamorphosized individuals of $A$. pehuenche in the occidental slopes of the Andes may be similar, in order of magnitude, to that mentioned by Corbalán et al. (2010) for the Argentinean side ("500 metamorphosized individuals"). The discovery of $A$. pehuenche in Chile (Corbalán et al. 2010) is one of a series of recent reports of range extension or new localities for various species in different zones of the country (e.g. Correa et al. 2008a, 2008b; Vidal \& Ortiz 2009; Correa et al. 2010; Cuevas \& Cifuentes 2010; Rabanal 2010; Rabanal \& Alarcón 2010; Cuevas 2011), but in this case, also it represents a new amphibian species for the country. Some of these recent reports involve species, which were known in very reduced geographic areas (Araya \& Riveros 2008; Correa et al. 2008a; Rabanal \& Alarcón 2010), which suggests that microendemism may be less common than had been supposed. This clearly shows that the knowledge of the biogeography of Chilean amphibians is precarious, thus it is necessary to increase exploration efforts to define distribution limits more precisely.

Finally, it is necessary to mention the consequences of our molecular findings for the conservation of $A$. pehuenche. Corbalán et al. (2010) mentioned concrete and potential threats for the type locality (contamination by vehicle particle emission, domestic animals, alteration of watercourses, natural floods and climate change), which may also affect the new localities of Chile reported in this article. Also, although the range was significantly extended, the molecular evidence obtained in this study suggests a low level of genetic variation, which is another potential threat to the persistence of the populations. However, it is necessary to obtain sequences of other, more variable, gene fragments to discard the low genetic variation as an additional threat to A. pehuenche throughout its range.

\section{ACKNOWLEDGMENTS}

We are especially grateful to Boris Blotto for providing the sequence of the specimen from Valle Pehuenche before its publication. C. Correa acknowledges the support provided by the postdoctoral project FONDECYT 3110040.

\section{BIBLIOGRAPHY}

AraYA, C. 2011. Estudio de la variabilidad cariotípica en Orestias (Teleostei: Cyprinodontidae): Caracterización de la heterocromatina constitutiva, mapeo de genes ribosomales y determinación de la cantidad de DNA nuclear. Tesis de Magíster. Universidad de Chile. Santiago, Chile.

Araya, S. \& Riveros, E. 2008. Ampliación del rango de distribución geográfica de Alsodes montanus (Amphibia: Leptodactylidae) a la Región de O’Higgins. Boletín del Museo Nacional de Historia Natural 57:117-123.

Blotto, B.L., NúÑez, J.J., Basso, N.G., Úbeda, C.A., Wheeler, W.C. \& Farvovich, J. 2013. Phylogenetic relationships of a Patagonian frog radiation, the Alsodes + Eupsophus clade (Anura: Alsodidae), with comments on the supposed paraphyly of Eupsophus. Cladistics 29(2):113-131.

CEI, J.M. 1976. Remarks on some neotropical amphibians of the genus Alsodes from southern Argentina. Atti della Società Italiana di Scienze Naturali e del Museo Civico di Storia Naturale di Milano 117(3-4):159-164.

CEI, J.M. 1980. Amphibians of Argentina. Monitore Zoologico Italiano, N.S. Monografia 2: i-xii, 1-609.

Cei, J.M. \& Roig, V.G. 1965. The systematic status and biology of Telmatobius montanus Lataste (Amphibia: Leptodactylidae). Copeia 1965(4):421-425.

Corbalán, V., Debandi, G. \& Martínez, F. 2010. Alsodes pehuenche (Anura: Cycloramphidae): Past, present and future. Cuadernos de Herpetología 24(1):17-23.

Correa, C., Sallaberry, M., Iturra, P., Collado, G. \& Méndez, M.A. 2008a. Amphibia, Anura, Cycloramphidae, Alsodes montanus: New record and geographic distribution map. Check List 4(4):467-471.

Correa, C., Sallaberry, M., Jara-Arancio, P., Lobos, G., Soto, E.R. \& Méndez, M.A. 2008B. Amphibia, Anura, Bufonidae, Rhinella atacamensis: Altitudinal distribution extension, new records and geographic distribution map. Check List 4(4):478-484.

Correa, C., Riveros, E., Lobos, G. \& Velásquez, N. 2010. Amphibia, Anura, Leiuperidae, Pleurodema thaul (Lesson, 1827): Altitudinal distribution extension and new records from its northern range. Check List 6(1):10-12.

Correa, C., Cisternas, J. \& Correa-Solís, M. 2011. Lista comentada de las especies de anfibios de Chile (Amphibia: Anura). Boletín de Biodiversidad de Chile 6:1-21.

Cuevas, C.C. 2008. A new species of the genus Alsodes (Anura: Neobatrachia) from the Nothofagus forest, Coastal Range, southern Chile, identified by its karyotype. Zootaxa 1771:43-53.

Cuevas, C.C. 2011. New geographic records of Telmatobufo australis Formas, 1972 (Amphibia, Anura, Calyptocephalellidae) in southern Chile. Boletín de Biodiversidad de Chile 5:28-35. 
Cuevas, C.C. \& Formas, J.R. 2001. A new species of Alsodes (Amphibia, Anura, Leptodactylidae) from Central Chile. Amphibia-Reptilia 22(2):187-198.

Cuevas, C.C. \& Formas, J.R. 2003. Cytogenetic analysis of four species of the genus Alsodes (Anura: Leptodactylidae) with comments about the karyological evolution of the genus. Hereditas 138(2):138-147.

Cuevas, C.C. \& Formas, J.R. 2005. A new frog of the genus Alsodes (Leptodactylidae) from the Tolhuaca National Park, Andes Range, southern Chile. Amphibia-Reptilia 26(1):39-48.

Cuevas, C.C. \& Cifuentes, S.L. 2010. Amphibia, Anura, Ceratophryidae, Batrachyla leptopus Bell, 1843: New records updating and geographic distribution map, Chile. Check List 6(4):633-636.

DiaZ, N.F. \& VALEnCIA, J. 1985. Larval morphology and phenetic relationships of the Chilean Alsodes, Telmatobius, Caudiverbera and Insuetophrynus (Anura: Leptodactylidae). Copeia 1:175-181.

Formas, J.R., Ubeda, C., Cuevas, C. \& Nuñez, J. 1997. Alsodes australis, a new species of Leptodactylid frog from the temperate Nothofagus forest of Southern Chile and Argentina. Studies on Neotropical Fauna and Environment 30:200-211.

Goebel, A.M., Donnelly, J.M. \& Atz, M.E. 1999. PCR primers and amplification methods for 12 s ribosomal DNA, the control region, cytochrome oxidase $\mathrm{I}$, and cytochrome $\mathrm{b}$ in bufonids and other frogs, and an overview of PCR primers which have amplified DNA in amphibians successfully. Molecular Phylogenetics and Evolution 11:163-199.
Hall, T.A. 1999. BioEdit: an user-friendly biological sequence alignment editor and analysis program for Windows 95/98/ NT. Nucleic Acids Symposium Series 41:95-98.

IUCN. 2012. The IUCN Red List of Threatened Species. Version 2012.2. URL: http://www.iucnredlist.org. Accessed: December 28, 2012.

Moritz, C., Schneider, C.J. \& Wake, D.B. 1992. Evolutionary relationships within the Ensatina eschscholtzii complex confirm the ring species interpretation. Systematic Biology 41(3):273-291.

National Research Council. 1996. Guide for the Care and Use of Laboratory Animals. Institute for Laboratory Animal Resources. National Academy Press, Washington, DC. $140 \mathrm{pp}$.

Rabanal, F.E. 2010. Amphibia, Anura, Ceratophryidae, Batrachyla nibaldoi Formas, 1997: Latitudinal extension in Patagonia, southern Chile, and distributional range actualization. Check List 6(2):287-288.

Rabanal, F.E. \& Alarcon, D. 2010. Amphibia, Anura, Cycloramphidae, Alsodes vanzolinii (Donoso-Barros, 1974): Rediscovery in nature, latitudinal and altitudinal extension in Nahuelbuta Range, southern Chile. Check List 6(3):362-363.

VIDAL, M.A. 2008. Biogeografía de anfibios y reptiles. In: Herpetología de Chile (Eds. Vidal, M.A. \& A. Labra), pp. 195-231. Science Verlag, Santiago, Chile.

VidAL, M.A. \& Ortiz, J.C. 2009. Amphibia, Anura, Ceratophryidae, Batrachyla leptopus Bell, 1843: Insular distribution extension, Chile. Check List 5(4):869-871.

Recibido: 14.06.13

Aceptado: 26.07.13 